\title{
Using Statistical Analysis to Investigate the Relevance of Accounting Information in Emerging Financial Markets: An Empirical Study
}

\author{
Walid Belassi ${ }^{1} \&$ Sherif S. Elbarrad ${ }^{2}$ \\ ${ }^{1}$ Department of Finance, Economics and Operations Management, Faculty of Business, Athabasca University, \\ Alberta, Canada \\ ${ }^{2}$ Department of Acounting \& Finance, School of Business, MacEwan University, Alberta, Canada \\ Correspondence: Walid Belassi, Faculty of Business, Athabasca University, 20113220 St. Albert Trail, \\ Edmonton, AB T5L 4W1, Canada. Tel: 1-866-795-1736. E-mail: walid@athabascau.ca
}

Both authors contributed equally to this paper.

Received: December 2, 2019

doi:10.5539/ass.v16n6p1
Accepted: May 14, $2020 \quad$ Online Published: May 31, 2020

URL: https://doi.org/10.5539/ass.v16n6p1

\begin{abstract}
Despite extensive literature and numerous published work on the area of value relevance of accounting information, a major part of the studies have been conducted on large and developed capital markets. While there are a number of published articles in the area of value relevance of accounting information in developing markets, there is still a need to investigate more developing markets to see if there are similarities or different attributes of each market that could shed more light on the importance and usefulness of accounting relevance in developing markets. To study further the gap of accounting relevance in developing markets, this study investigates the relationship between the accounting information - represented in the financial ratios, F-Score, M-Score, in addition to market-related measures - and stock price represented in the ratio of Price to Book Value (PBV) per share and Price-Earnings (PE) Ratio. In order to shed light on the significant variables that affect the stock price in emerging markets, this study examines the cement sector in Saudi Arabia. The results of the study indicate that F-score, inventory turnover, current ratio, debt-to-equity ratio, return on assets, and average trading are significant determinants of PBV. Combined, they explain $75.1 \%$ of the variations in PBV. The study also shows that F-score and inventory turnover are significant determinants of PE. Combined, they explain $23.1 \%$ of the variations in PE.
\end{abstract}

Keywords: financial markets, emerging financial markets, accounting, finance, relevance of accounting information

\section{Introduction}

There is a lack of research on the value relevance of accounting information in emerging markets (Alfaraih \& Alanezi, 2011). An increasing gap between market and book values of equity in most countries is a significant signal of the loss of the relevance of accounting information and may signify the need for other kinds of information in order to explain the intrinsic value of equity (Abuzayed, Molyneux, \& Al-Fayoumi, 2009). Some scholars (Pervan \& Bartulović, 2014) even go further to state that accounting information is considered value relevant if it is correlated with the market value of a company. If there is no statistically significant relationship between accounting information and the market value of a company, it can be concluded that accounting information is irrelevant, which implies that financial statements do not meet one of the fundamental objectives of financial reporting.

Despite the extensive research in the area of value relevance, it is important to notice that the majority of studies are conducted on large and developed capital markets, and that few studies are conducted on small and developing capital markets (Pervan \& Bartulović, 2014). To a great extent, accounting theory has been relatively silent on the role of accounting in "possibly" inefficient and emerging markets, despite the fact that one should expect accounting to be less relevant in those markets because price fails to reflect information regarding stock prices due to a variety of market problems (Lopes, 2002).

Since investors use PBV and PE, among other measures, for making sound investment decisions, in this study we attempt to research the relationship between the accounting information and PBV and PE of stocks that are 
traded in an emerging market. In particular, our goal is to study the effects of the different financial ratios, $\mathrm{M}$-Score and F-score, as indicators of accounting information on PBV and PE; as indicators of market valuation of the company, and hence, its performance. PBV ratio is calculated based on the relation between the stock's price and its book value. It is by nature related to figures derived from the stock market (price) and figures related to the statement of financial position (net book value). PE ratio is calculated based on the stock price and its earnings. Earnings are collected from the income statement. Understanding the relationship of the financial ratios with these two market-related ratios should shed the light on the relevance of the information-driven from those two financial statements to stock performance.

Applying the study to an emerging market provides more understanding of the relevance of accounting information in those markets. It also provides investors in emerging markets with valuable information that could help them make sound investment decisions by spotting under or overvalued stocks.

In particular, this research aims to achieve the following goals:

Identify the financial and market-related information that explain the changes in both PBV and PE ratios.

Develop two statistical models to predict the PBV ratio and PE ratio respectively, based on the financial and market information provided.

The remainder of this paper is structured as follows: section two represents the literature review; section three covers the research methodology; the empirical findings are discussed in section four; the limitations of the study and future research are discussed in section five; and section six presents the conclusion of the study.

\section{Literature Review}

PBV ratio has been used in several studies to estimate stock returns. Several studies, such as Pandey, Asheesh \& Sehgal (2010); Alcock \& Gray (2005); and Jensen, Johnson \& Mercer (1997) support the idea that PBV is one of the best price predictors, especially in comparison with other measures such as multipliers, price-to-cash flow or price-to-sales. A company's share price represents investors' assessments of future prospects, while its book value represents accountants' representation of its past net assets cost. Therefore, the greater a company's prospects for future growth, the higher the PBV ratio (Dunis \& Reilly, 2004).

Low PBV ratio is usually an indication of a value stock. These stocks are profitable in the long run. As indicated by Dreman (1996), investing in the lowest price-to-book group in 1970 would have returned 36 times the original investment by the end of 1994. This is more than double the return of the market as a whole. Bajkowski (2001) indicates that measures such as the PBV ratio help identify which stocks may be truly undervalued and neglected. Another study (Asebedo \& Grable, 2004) concluded that the PBV ratio had the highest adjustment factor and had been set as the best stock valuation model. Further, Chan, Hamao \& Lakonishok (1991) found a strong correlation between PBV and average returns for the Japanese market. Similarly, in the Korean Stock Market, in general, returns are positively related to price-to-book ratio, sales price, and debt-equity ratios. Dhatt, Kim \& Mukherji (1999) also conclude that among the explanatory factors examined, PBV ratio generally has the greatest predictive power for stock returns. This is confirmed by another research that stated that it is now a well-established fact that PBV and firm size are two characteristics that best explain stock returns in the US and Japan. Akdeniz et al. (2000) also found book value to be a more robust measure of firm size than market value. Ganos (2000) also confirms the positive relationship between book value and return, indicating that larger companies do better than smaller companies on average, despite the bias in their data that is in favor of smaller companies.

Aras \& Yilmaz (2008) conclude that the price-to-book ratio stands among others in revealing significant results in terms of predicting stock returns for a one-year period for most of the emerging market countries. Another study by Moridipour \& Farrahipour (2013) investigated the relationship of PBV with several financial ratios on the Tehran Stock market. They conclude that PBV has no significant positive relationship with profitability. However, it has a significant positive relationship with other financial ratios such as liquidity, return on equity and assets efficiency ratios.

Many studies emphasize the importance of PBV. PBV ratio contains information about future returns that is not captured by other variables such as interest yield spreads and dividend yields. The predictive ability of price-to-book ratio appears to stem from the relationship between future earnings and book value (Pontiff, Jeffrey, \& Schall, 2011). In their study, Bali, Cakici \& Fabozzi (2013) provide evidence for a positive significant link between the price-to-book ratio and the cross-section of expected return for all countries and almost all market capitalization groups. While, on one hand, the previous studies emphasize the importance of PBV, other studies, such as Bodhanwala (2014), focus on the (PE) ratio in assessing the value and growth rate of 
organizations. Al-Mwalla, Al-Omari, \& Ayad (2010) focused on the importance of PE ratio in a developed market where they concluded that there is a long run equilibrium between dividend yield, PE ratio, size of the firm and the return on stocks. Kyriazis and Christou (2013) found evidence that stocks with low PE ratio yield more return on investment in the long term. Penkar and Deo (2010) compared PE ratios in different industries and regions and found that they vary significantly. Shen (2000) indicated that a PE ratio above the historical average is usually followed by a slow long-term growth in stock prices. Asiri and Hameed (2014) suggest that a high PE ratio indicates strong shareholder confidence in the company and its future, and vice versa. While this may be true for developed markets, we believe it may not apply to emerging markets. With the lack of information in developing markets, a high PE ratio could simply mean that the company is overpriced. Bodhanwala (2014) found that portfolios of stocks that are formed on the basis of low PE ratio outperformed the average market returns in non-efficient markets. Moreover, Wu \& Boston (2014) found evidence that the forward PE ratio explains stock prices better than other historically-based financial ratios. It is worth noting that $\mathrm{Wu}$ and Boston's (2014) study focused on developed markets; their conclusion might not be true in emerging markets. Accordingly, in this study, we will shed light on whether or not PE is the best indicator of share value in emerging markets.

Other studies investigate the relation between PBV and PE. Bekaert, Geert and Havey (1997) conclude that variables like average PE and PBV ratios are reported to have some explanatory power for average market returns. Nezlobin, Rajan \& Reichelstein (2016) examined the structural properties of PE and PBV ratios and the relationship between them. Their results show that both ratios are jointly shaped by several key variables. Nettayanun (2017) defines value stocks as either having a low PBV ratio or a low PE ratio. This implies that the type of market being studied (developed vs. emerging) could influence the ratios that should be considered when studying that market. Nettayanum's (2017) definition strengthens the value of this study because it is focused on an emerging market, which could be unique in terms of the ratios that should be studied in order to better understand the market's behavior.

It is evident from the literature that PBV and PE each has its own strengths and ability to explain and predict a stock's performance, especially in an emerging market. Accordingly, in our study we will investigate both ratios and their relationships with the financial ratios. We expand our analysis to include, not only the traditional and well proven financial ratios, but to include other market related ratios such as F-Score and M-Score. Our study will entirely focus on emerging markets.

To the best of our knowledge, there are only few studies such as (Asiri, 2015), (Asiri, 2015) that considered studying the relationship between some financial ratios and PBV and PE in emerging markets to see if any of those ratios could explain the changes in the PBV and PE ratios. Asiri's study focused on the Bahrain's Stock Market.Asiri's study does not include the whole spectrum of ratios and market indicators that we include in this study. Reza \& Leila,( 2013) studied the predictability of stock returns using financial ratios in Tehran Stock Exchange. They concluded that there is an effective relationship between the ratio of PE and PBV to market value of stock return. Taani, Khalaf \& Banykhaled, ( 2011) studied the effect of accounting information on EPS by using five categories of financial ratios applying their study on the Jordanian Industrial Sector. They concluded that Return on Equity, Debt to Equity ratio, and cash flow from operating activities affect EPS.

Since one of our goals is to focus the investors' attention on useful financial ratios that helps them understand the changes in both PBV and PE as predictors of how stock price could fluctuate, we include, in addition to all the traditional financial ratios (as indicated earlier), the F-Score developed by Piotroski (2000) among the financial ratios we study. F-Score has been gaining increasing attention in the last few years. Several scholars, such as Le et al. (2018), Hall (2015), and Briginshaw (2003) studied F-Score and its ability to spot value stock, whether alone or in conjunction with other ratios. Their results indicate that F-Score has always been a significant variable in spotting value stocks. These results encouraged the authors to include F-Score among the set of variables that are used to predict PBV and PE in this research.

F-Score helps in identifying value companies. Value companies are companies whose securities can be purchased at prices that are relatively lower than their estimated underlying values (Dunis \& Reilly, 2004). Piotroski (2000) created a nine-signal based score (F-Score) to identify value stocks. For detailed information on how F-Score is calculated and the variables used to calculate it, we refer the reader to Piotroski (2000) for a detailed discussion on F-Score.

Chung et al. (2015) stresses the usefulness of F-Score, especially when it comes to determining value stocks. They indicate that F-Score has several advantages over existing single measures for capturing the effectiveness of institutional monitoring. Firstly, F-Score is constructed from nine fundamental signals and hence, is a more 
comprehensive measure of a firm's financial health. Secondly, individual measures could imply contradicting results. For instance, if PBV or PE ratios of a particular firm are high, this could indicate that the company's stock is overpriced or that its prospects are high. On the other hand, if the PBV or PE ratios are low, this could indicate that the company's prospects are low, or that the stock is underpriced, which is regarded as a value stock. To be able to distinguish between the two possibilities in each case - that is, whether the stock is overpriced or the prospects of the company is high, in the case of a high PBV or PE, and whether the stock is underpriced (value stock) or the prospects of the company are low, in the case of a company with a low PBV or PE-we include F-Score in this study to comprise its ability to explain the changes in both ratios.

Similar to other researchers (see for instance Upadhyay \& Bandyopadhyay, 2012), Piotroski (2000) supports the idea that the combined use of relevant performance metrics, such as F-Score or a DuPont-style analysis, simply improves the ability of an investor to distinguish strong companies from weak companies relative to the success garnered from a single, historical measure. Piotroski (2000) and Hyde (2014) emphasize the idea of using F-Score in emerging markets by stating that the lower informational efficiency of emerging markets could plausibly result in the F-Score having even more power in emerging markets than developed markets. Hall (2015) tested F-Score across a range of valuation metrics. His tests produced results that indicate the usefulness of F-Score.

In addition to F-Score, Beneish (1999) conducted a study in which he developed the M-Score in order to identify the companies that might be manipulating their earnings. The model's variables are designed to capture either the financial statement distortions that can result from manipulation, or preconditions that might prompt companies to engage in such activity. The model is composed of eight variables. For detailed information about how M-Score is calculated, we refer the reader to Beneish's study. Studying the relationship between M-score and both PBV and PE is important as it indicates whether earnings manipulation ultimately has an effect on the value of both ratios.

In addition to F-Score and M-Score, we also test the effects of traditional financial ratios on PBV and PE. We will discuss this in detail in the following section.

\section{Research Methodology}

\subsection{Sample Selection}

\section{Relative Market Capitalization}

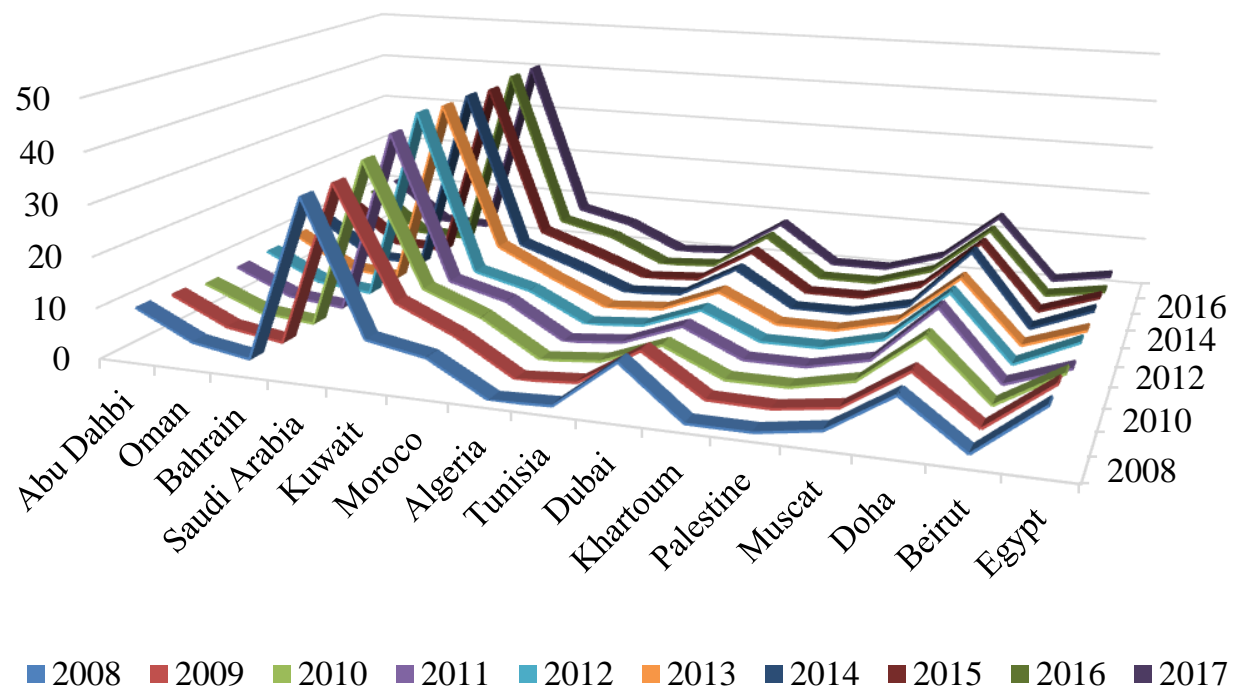

Figure 1. Relative Market Capitalization of the Arab Countries for the period 2008 - 2017

Previous studies covered financial markets in several developing countries. However, very few studies covered markets in the Middle East. This study focuses on the cement sector in the Saudi Arabian stock exchange. The Saudi Arabian Stock Market is chosen as it is one of the emerging stock markets and it has been exposed to a crash in 2009, thus investors need to rely more on accounting information to take an informed decision. In addition, the Middle East area has very few published research papers in English due to language difference. In 
terms of capitalization, it ranks as the largest stock market in the Arab world (Alshogeathri, 2011). Figure 1 shows the relative market capitalization of the different Arab countries; it is evident that the Saudi Arabian market has consistently been the largest in the last 10 years (Arab Monetary Fund, 2008 - 2017), and is thus worth studying.

While the Saudi Arabian stock market includes many industries, the cement sector has been chosen due to its relative stability and independence from irregular economic fluctuations. Because our study focuses on emerging markets, it was important to select an industry that is relatively stable in order to avoid introducing another source of noise to our data. The cement industry relies on the construction industry, which has always been growing and has not been affected by economic conditions, thus providing the necessary level of stability in the cement sector.

The cement sector consists of fourteen companies that are all traded on the stock market. All fourteen companies are considered in our study. Their financial statements covering the period from $2008-2015$ are collected and studied. Out of the fourteen companies, five of them didn't have financial statements covering the entire period of the study. Accordingly, they have been excluded from further analysis. The financial statements of the remaining nine companies are analyzed, and a group of financial ratios, including profitability, solvency, liquidity, asset management ratios, F-Score, M-Score, price-to-book ratio, and market analysis indicators are calculated.

\subsection{Preparation of Data}

Since the study's main objective is to determine the relevance of accounting information-represented in financial ratios - in emerging markets, the authors prepared the data in a way that follows the traditional classification of financial ratios in the accounting literature.

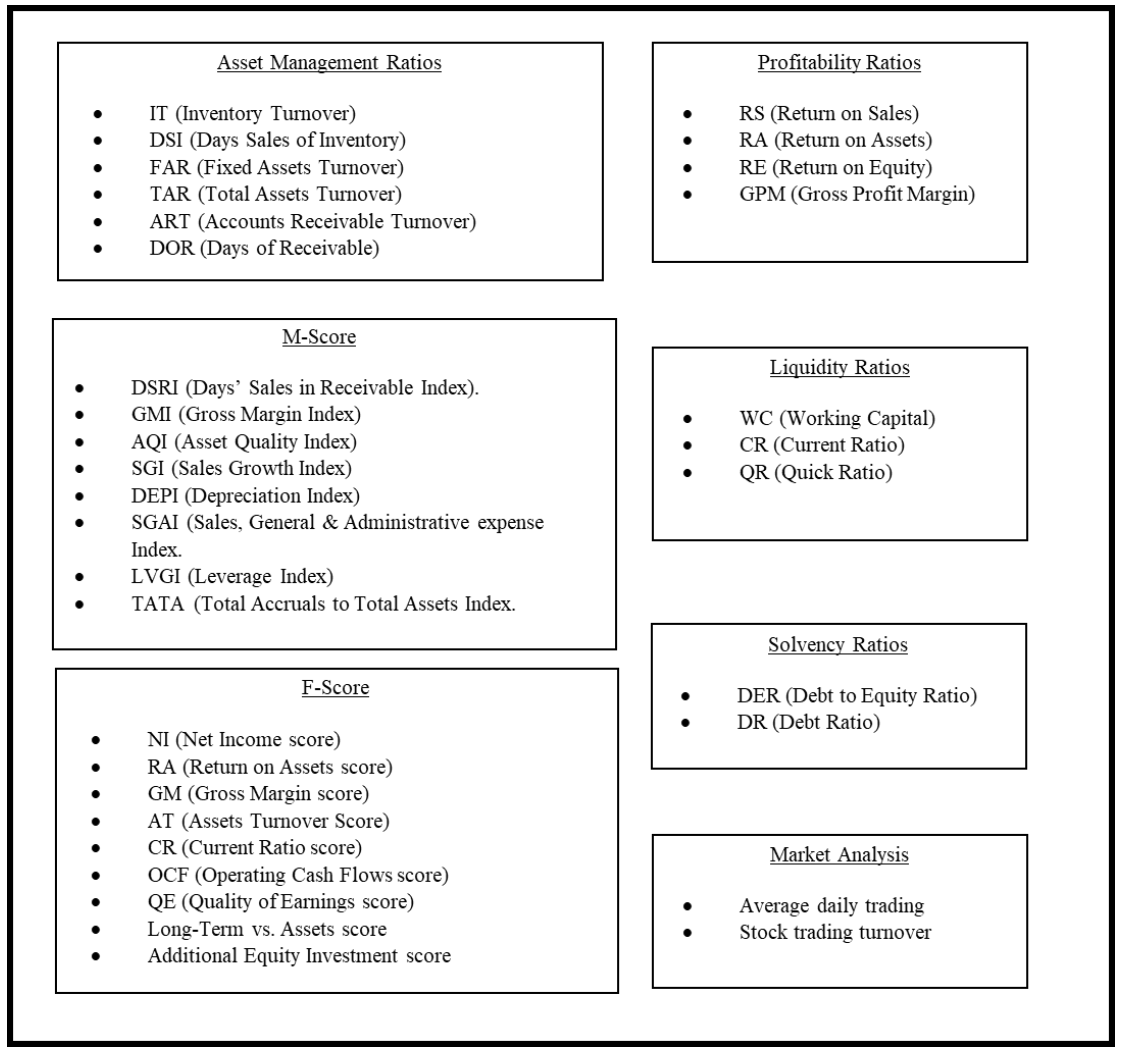

Figure 2. Financial Ratios

In general terms, financial ratios are divided mainly into four groups: asset management ratios, profitability ratios, solvency ratios, and liquidity ratios. Additionally, we included market analysis ratios. The financial and market analysis ratios representing all groups were calculated for all nine companies in the cement industry. In addition to the financial ratios just mentioned, we also calculated the F-Score for all nine companies. F-Score is calculated as a factor, which consists of nine scores that can either have a value of zero or one depending on the direction of change in the following variables: net assets, return on assets, gross margin, asset turnover, current 
ratio, operating cash flow, quality of earnings, long term debts vs. assets, and additional equity investment. In this study, F-Score has been measured as suggested by Piotroski (2000). We also included M-Score, as previously discussed in the literature review section.

Figure 2 represents the different groups of financial ratios, what they measure, and the individual ratios constituting each group.

In order to study the effects of financial ratios, it is crucial to include all financial ratios listed above and be as comprehensive as possible. However, since the financial ratios in each group are highly correlated, including all financial ratios would lead to a multicollinearity problem, which would jeopardise the reliability of our results. To overcome this problem, we developed the following criteria for selecting the financial ratios from each group that would be included in the empirical study:

1) All groups of financial ratios must be included in the empirical model.

2) To avoid multicollinearity resulting from the high correlation among the ratios in the same groups, only one financial ratio would be selected from each group.

3) The financial ratio selected from each group must represent its groups. In other words, the financial ratio selected must align with the following guidelines:

a) There is high correlation with the other financial ratios in its group.

b) Its effect on the dependent variables (PBV and PE) is not significantly different from the effect of the rest of the ratios in the same group; in other words, the ratio selected must be representative of its group. However, since the objective of this study is exploratory in nature, we believe that it is more beneficial to find as many significant relationships as possible, which can be verified later in a confirmatory study. Hence, we selected ratios with high correlation with the dependent variables (PBV and PE) when all other things were equal.

4) The financial ratio selected should not violate any of the conditions of the statistical tool (multiple regression analysis) used to analyze the data. This is to ensure valid results and reliable interpretation of the relationships among the variables.

With the previous criteria in mind, the following variables in particular are included in this study:

- $\quad$ F-Score, which ranges between a score of 0 to 9

- Inventory turnover ratio representing asset management ratios. While Fixed Assets Turnover (FAR) and Total Assets Turnover (TAR) might appear to be better representatives of this group, asset management ratios, FAR, and TAR were not included in our model due to their high correlation with many other independent variables selected in our empirical analysis. Their inclusion would have led to a significant multicollinearity problem, which would have rendered the results of our model unreliable.

- Current ratio representing liquidity ratios

- Total accruals to total assets ratio, representing M-Score

- Debt to equity ratio, representing solvency ratios

- Returns on assets, representing profitability ratios

- Average daily trading of stocks, representing market analysis ratios. The daily trading data for each stock for each company for the period of the study is captured and used to calculate the average annual daily trading of each stock.

- $\quad$ Price-to-book value (PBV), calculated on a daily basis based on the stock's closing price per day and the book value per share as per the Statement of Financial Position. The average PBV is then calculated per year.

- $\quad$ PE ratio, calculated on a daily basis based on the stock's closing price per day and using the earnings reported on the annual Income Statement. The average PE is then calculated per year.

Since emerging markets have the possibility of being inefficient financial markets, financial data extracted from them could be less than ideal and must be checked before applying any reliable statistical analysis. The researchers checked the data for all the assumptions of linear regression. While the data met the conditions of linear relationships, multicollinearity, autocorrelation, and heteroscedasticity, three variables did not pass the test of normality. In particular, average trading (TRDNG), debt to equity ratio (DER), and inventory turnover (IT) proved to be not normally distributed. The variables were adjusted and their log values were used instead. 
Accordingly, LOG_TRDNG, LOG_DER, and LOG_IT will replace the original variables from this point forward.

\section{Research Model}

As indicated earlier, the main objective of this study is to investigate the variables that affect PBV and PE. To study the effects of the different financial ratios, including F-Score and M-Score, on PBV and PE, we use multiple regression analysis. We developed two regression models, each to predict one of the two dependent variables. Our hypothesized models are as follows:

Model 1:

$\mathrm{PBV}=\beta 0+\beta 1$ FSCORE $+\beta 2 \mathrm{LOG} \_\mathrm{IT}+\beta 3 \mathrm{CR}+\beta 4$ TATA $+\beta 5$ LOG_DER $+\beta 6$ RA $+\beta 7$ LOG_TRDNG $+\mathrm{e}$ Model 2:

$$
\mathrm{PE}=\beta 0+\beta 1 \mathrm{FSCORE}+\beta 2 \mathrm{LOG} \_\mathrm{IT}+\beta 3 \mathrm{CR}+\beta 4 \mathrm{TATA}+\beta 5 \text { LOG_DER }+\beta 6 \mathrm{RA}+\beta 7 \text { LOG_TRDNG }+\mathrm{e}
$$

Where,

- $\quad$ PBV is Price to Book value

- $\quad$ PE is Price to Earnings ratio

- FSCORE is the F-Score

- LOG_IT is the natural log of inventory turnover ratio

- $\quad \mathrm{CR}$ is the current ratio

- TATA is the total accruals to total assets ratio

- $\quad$ LOG_DER is the natural log of debt to equity ratio

- $\quad$ RA is the return on assets ratio

- LOG_TRDNG is the natural log of the average daily trading of a company's stock

- $\mathrm{e}$ is the error term

The model for PBV is presented in Figure 3. Similarly, the model for PE is presented in Figure 4.

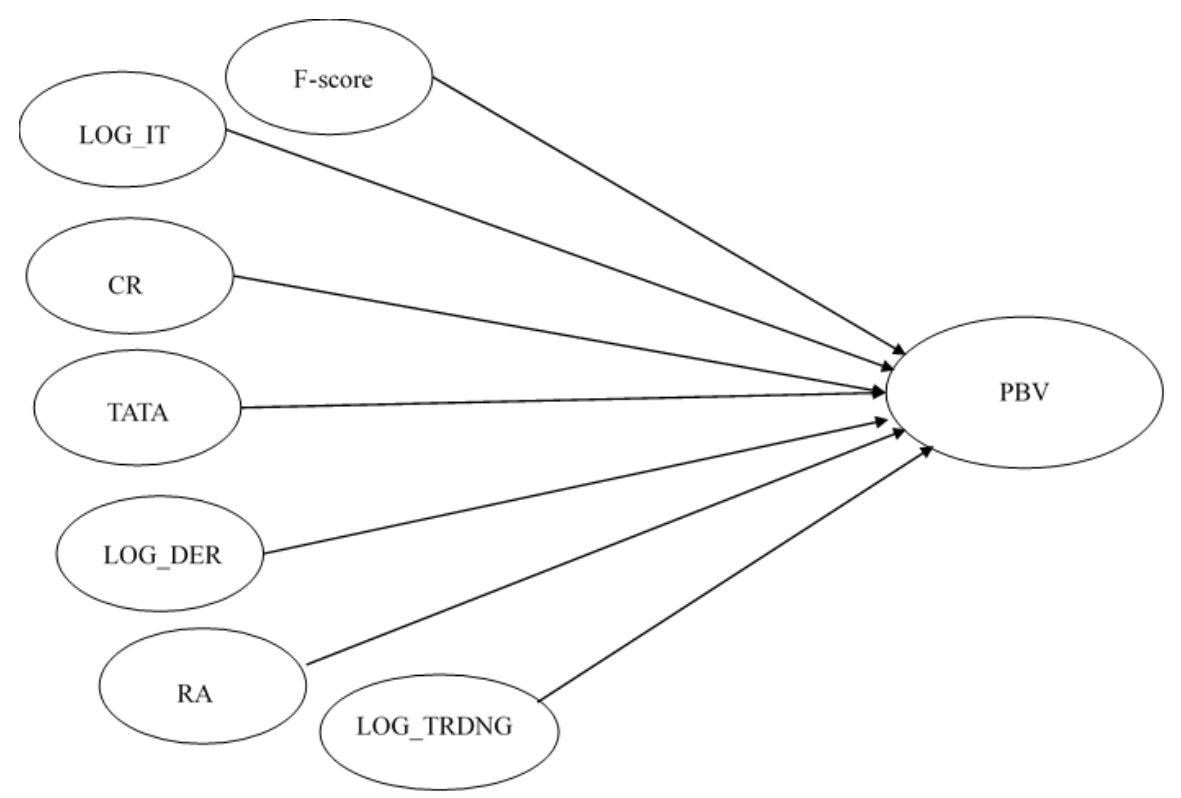

Figure 3. The Effects of Accounting Information on PBV 


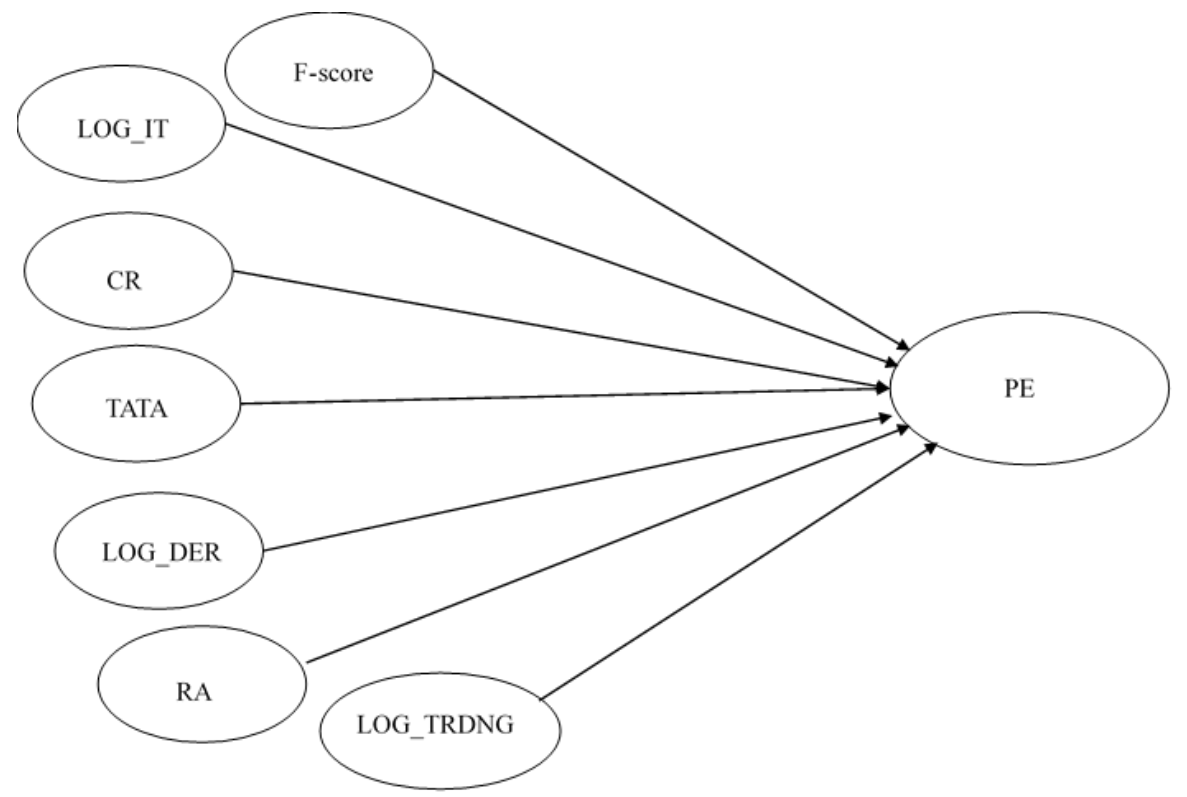

Figure 4. The Effects of Accounting Information on PE

We test the significance of the effects of financial ratios on both PBV and PE in the cement industry in Saudi Arabia in the following section.

Our assumption is that both PBV and PE have a negative relationship with F-Score, as low PBV or PE might be an indication of value stock, and high F-Score is an indication of value stock. Hence,

- $\mathrm{H}_{1}$ : The higher the F-Score of an organization operating in an emerging market, the lower its PBV ratio

- $\mathrm{H}_{2}$ : The higher the F-Score of an organization operating in an emerging market, the lower its PE ratio

We assume that a higher IT ratio indicates better efficiency of managing inventory, and it could also be an indication of higher sales that result in higher profitability. If the stock market is reacting positively to the efficiency of managing inventory, both PBV and PE should also be affected in the same direction. Hence,

- $\mathrm{H}_{3}$ : The higher the IT ratio of an organization operating in an emerging market, the higher its PBV ratio.

- $\mathrm{H}_{4}$ : The higher the IT ratio of an organization operating in an emerging market, the higher its PE ratio.

We expect a positive relationship between current ratio and both PBV and PE of an organization, seeing as the financial stability of an organization, represented in its high CR, should be reflected in its PBV and PE. Thus, we expect that if the market is efficient and reflects this information, an organization with a higher current ratio should have a higher PBV and PE compared to its counterpart with a relatively lower current ratio. We expect such relationships to also exist in emerging markets. Hence,

- $\mathrm{H}_{5}$ : The higher the current ratio of an organization operating in an emerging market, the higher its PBV ratio.

- $\mathrm{H}_{6}$ : The higher the current ratio of an organization operating in an emerging market, the higher its PE ratio.

Similarly, we expect a positive relationship between total accruals to total assets and returns on assets ratios, and both PBV and PE. Hence,

- $\mathrm{H}_{7}$ : The higher the total accruals to total assets ratio of an organization operating in an emerging market, the higher its PBV ratio.

- $\mathrm{H}_{8}$ : The higher the total accruals to total assets ratio of an organization operating in an emerging market, the higher its PE ratio.

- $\mathrm{H}_{9}$ : The higher the return on assets ratio of an organization operating in an emerging market, the higher its PBV ratio.

- $\mathrm{H}_{10}$ : The higher the return on assets ratio of an organization operating in an emerging market, the higher its PE ratio.

We also expect a positive relationship between the average daily trading of a stock and both the PBV and PE of 
its organization. We are assuming that when the average daily trading of stock is high, the investors who are buying the stock are expecting that it is of value, thus increasing its PBV and PE. Hence,

- $\mathrm{H}_{11}$ : The higher the average daily trading of an organization operating in an emerging market, the higher its PBV ratio.

- $\mathrm{H}_{12}$ : The higher the average daily trading ratio of an organization operating in an emerging market, the higher its PE ratio.

On the contrary, we expect a negative relationship between debt-to-equity ratio and both PBV and PE. As the debt-to-equity ratio of an organization goes up, the riskier the organization is. Thus, we expect its PBV and PE to be relatively low compared to a similar organization with a lower debt-to-equity ratio. Hence,

- $\mathrm{H}_{13}$ : The higher the debt-to-equity ratio of an organization operating in an emerging market, the lower its PBV ratio.

- $\mathrm{H}_{14}$ : The higher the debt-to-equity ratio of an organization operating in an emerging market, the lower its PE ratio.

\section{Discussion}

We tested our proposed regression models on all nine companies in the cement industry. The intercept, coefficient value, $\mathrm{t}$-values, adjusted $\mathrm{R}$-squared and significance $\mathrm{F}$ values are displayed in Table 1.

Table 1. Regression Model Results - PBV \& PE

\begin{tabular}{|c|c|c|}
\hline \multirow[b]{2}{*}{ Explanatory Variables } & \multicolumn{2}{|c|}{ Dependent Variables } \\
\hline & PBV & $\mathbf{P E}$ \\
\hline \multirow[t]{2}{*}{ Intercept } & 0.924 & 16.21 \\
\hline & 2.47 & 6.28 \\
\hline \multirow[t]{2}{*}{ F-Score } & -0.19 & -0.85 \\
\hline & $-4.79^{* * *}$ & $-2.90 * * *$ \\
\hline \multirow[t]{2}{*}{ LOG_IT } & 0.76 & 2.52 \\
\hline & $3.48^{* * *}$ & $1.68^{*}$ \\
\hline \multirow[t]{2}{*}{$\mathrm{CR}$} & 0.14 & 0.04 \\
\hline & $1.83 *$ & 0.08 \\
\hline \multirow[t]{2}{*}{ TATA } & 0.14 & 1.67 \\
\hline & 0.17 & 0.3 \\
\hline \multirow[t]{2}{*}{ LOG_DER } & -0.79 & -2.49 \\
\hline & $-1.95 *$ & -0.89 \\
\hline \multirow[t]{2}{*}{ RA } & 14.23 & -10.72 \\
\hline & $10.52 * * *$ & -1.1 \\
\hline \multirow[t]{2}{*}{ LOG_TRDNG (in 100,000) } & 0.64 & 0.58 \\
\hline & $3.21 * * *$ & 0.42 \\
\hline Significance F & $0.000 * * *$ & $0.000^{* * *}$ \\
\hline Adjusted R2 & 0.747 & 0.211 \\
\hline
\end{tabular}

Note: Figures in parentheses are $t$ ratios.

$* * *, * *$, and $*$ indicate the level of significance at $1 \%, 5 \%$, and $10 \%$, respectively.

The following conclusions could be deduced by studying the above results:

1) F-Score showed an inverse relationship with both PBV and PE as expected; Thus, $\mathrm{H}_{1}$ and $\mathrm{H}_{2}$ were supported. This confirms the results achieved by Piotroski (2000). It also confirms Dunis \& Reilly's (2004) definition of "value stock", being the stocks that can be purchased at prices that are relatively lower than their estimated underlying values. The high significance of F-Score supports Hyde's (2014) conclusion that F-Score would have more power in emerging markets than developed markets.

2) Log of inventory turnover ratio has a significant positive relationship with PBV as expected; thus, $\mathrm{H}_{3}$ was supported. Log of inventory turnover ratio has a significant positive relationship with $\mathrm{PE}$ at the $90 \%$ 
confidence level; thus, $\mathrm{H}_{4}$ was partially supported.

3) Current Ratio has a significant relationship with PBV at the $90 \%$ confidence level; thus, $\mathrm{H}_{5}$ was partially supported. Current ratio proved to have a positive, but insignificant, relationship with PE; thus, $\mathrm{H}_{6}$ is not supported. These results do not align with the study by Purwanto \& Agustin (2017), which showed a significant negative relationship between CR and PBV in the basic industry and chemical sector. The rationale behind Purwanto and Agustin's findings is that higher liquidity might indicate inefficiency in managing a firm's assets. Our study shows that a higher Current Ratio in emerging markets is an indication of a higher PBV. One possible explanation for this is that organizations with strong financial positions operating in emerging and less-efficient markets tend to support their financial and operating positions by having liquidity on hand in order to deal with any unforeseen uncertainties. Nevertheless, further investigation of the relationship between Current Ratio on one side, and PBV and PE on the other side in emerging markets could be a topic for future research.

4) TATA shows the estimates of the short-term forecasted inflow and outflow activities of a company. Excluding any significant changes within the company, these accruals should be fairly consistent within some acceptable statistical variation. As a result, higher positive accruals are associated with the potential for earnings manipulation (Warshavsky, 2012). When testing our model, TATA showed a positive but insignificant effect on both PBV and PE. Thus, $\mathrm{H}_{7}$ and $\mathrm{H}_{8}$ were not supported. A possible explanation for the insignificant effects of TATA on PBV and PE is that a higher TATA ratio indicates that the business's earnings are of low quality, since accruals represent a greater portion of the company's earnings. Nevertheless, further study on the relationship between TATA and PBV and PE is a valid topic for future research.

5) Return on Assets (RA) showed a significant positive relationship with PBV; thus, $\mathrm{H}_{9}$ was supported. This finding is reasonable, as most of the investment in long-term assets for most companies in the cement industry happens at the beginning of the company's life. Thus, assets which represent the denominator of the return on asset equation is almost constant. When RA increases as a result of efficient utilization of the assets, any slight increase in the stock's price will result in increase of PBV. This result is not aligned with the results achieved by another study (Şamilloğlu, Öztop \& Kahraman, 2017) applied on Istanbul Stock Exchange, where they found no significant relationship between the two ratios. However, several studies -such as Moridipour \& Farrahipour's (2013) on Tehran Stock Exchange, Marangu \& Jagongo's (2014) on the Nairobi Securities Exchange, and Purwanto \& Agustin's (2017) on the Indonesian Stock Exchange - confirm our results of a positive significant relationship between RA and PBV.

6) On the other hand, RA showed a negative but insignificant relationship with PE; thus, $\mathrm{H}_{10}$ was not supported. Instead, our findings proved the opposite of our hypothesis. However, this confirms the findings of several other studies (Şamiloğlu et al., 2017; Shamsudin, Mahmood \& Ismail, 2013; and Asiri, 2014). A higher RA is a measure of good performance. On the other hand, good performance increases earnings, and in the absence of an efficient market, the sensitivity of the stock's price to acknowledge such performance is low and does not respond quickly to the increase in earnings. With the increase in earnings, without the equivalent increase in price, PE ratio decreases, at least in the short run.

7) The natural log of trading turnover (LOG_TRDNG) showed a significant positive relationship with PBV; thus, $\mathrm{H}_{11}$ was supported. As for PE, LOG_TRDNG proved to be positive but insignificant; thus, $\mathrm{H}_{12}$ was not supported.

8) The natural log of debt to equity ratio (LOG_DER) shows a negative and significant relationship with PBV at the $90 \%$ confidence level. Accordingly, $\mathrm{H}_{13}$ was partially supported. Our findings of a negative relationship between debt to equity ratio PBV, align with another study (Purwanto \& Agustin, 2017) where it is concluded that DER has inverse relationship with PBV.

9) As expected in $\mathrm{H}_{14}$, LOG_DER showed a negative relationship with PE ratio. However, the relationship proved to be insignificant. Thus, $\mathrm{H}_{14}$ was not supported.

A summary of these results as they pertain to the hypotheses is provided in Table 2 .

As indicated in Table 1, the proposed model for PBV (Model 1) proved to be significant at the $99 \%$ confidence level (F < .01). The model explains $74.7 \%$ of the variation in PBV. F-Score, LOG_IT, CR, RA, LOG_DER, and LOG_TRDNG proved to be the significant determinants of PBV in the cement industry in Saudi Arabia.

Table 2. Summary of the Results of Testing the Hypotheses 


\begin{tabular}{cccc}
\hline & PBV & & PE \\
\hline Hypotheses & Supported/Rejected & Hypotheses & Supported/Rejected \\
\hline $\mathrm{H}_{1}$ & Supported & $\mathrm{H}_{2}$ & Supported \\
$\mathrm{H}_{3}$ & Supported & $\mathrm{H}_{4}$ & Partially supported \\
$\mathrm{H}_{5}$ & Partially supported & $\mathrm{H}_{6}$ & Not supported \\
$\mathrm{H}_{7}$ & Not supported & $\mathrm{H}_{8}$ & Not supported \\
$\mathrm{H}_{9}$ & Supported & $\mathrm{H}_{10}$ & Not supported \\
$\mathrm{H}_{11}$ & Supported & $\mathrm{H}_{12}$ & Not supported \\
$\mathrm{H}_{13}$ & Partially supported & $\mathrm{H}_{14}$ & Not supported \\
\hline
\end{tabular}

Similarly, the regression model for PE (Model 2) proved to be significant at the $99 \%$ level of significance (significance $\mathrm{F}=0.00$ ). The model explains $21.1 \%$ of the variation in PE. In particular, F-Score and LOG_IT proved to be the significant variables in determining $\mathrm{PE}$.

To enhance Models 1 and 2, we used the backward elimination procedure, which yielded the following two finalized models for PBV and PE, respectively:

PBV $=0.91-0.19 *$ FSCORE $+0.75 *$ LOG_IT +0.14 CR -0.8 LOG_DER + 14.26 RA + $0.65 *$ LOG_TRDNG

$\mathrm{PE}=15.9-0.79 * \mathrm{FSCORE}+3.08 *$ LOG_IT

Table 3 presents the results of the refined models using the backward elimination procedure.

Table 3. PBV \& PE Regression Models using the Backward Elimination Procedure

\begin{tabular}{lll}
\hline & Dependent Variables & \\
\hline Explanatory Variables & PBV & PE \\
\hline Intercept & 0.91 & 15.90 \\
& 2.51 & 8.54 \\
F-Score & -0.19 & -0.79 \\
& $-4.52^{* * *}$ & $-2.81^{* * *}$ \\
LOG_IT & 0.75 & 3.08 \\
& $3.50^{* * *}$ & $2.69^{* * *}$ \\
CR & 0.14 & - \\
LOG_DER & $1.89^{*}$ & - \\
RA & -0.8 & - \\
& $-2.12^{* *}$ & - \\
LOG_TRDNG (in 100,000) & 14.26 & - \\
Significance F & $10.73^{* * *}$ & - \\
Adjusted R2 & 0.65 & - \\
\hline
\end{tabular}

Note. Figures in parentheses are $t$ ratios.

$* * *, * *$, and $*$ indicate the level of significance at $1 \%, 5 \%$, and $10 \%$, respectively.

As indicated in Table 3, the enhanced regression models proved to be significant, and they explain $75.1 \%$ and $23.1 \%$ of the variation in PBV and PE, respectively.

When comparing both models (PBV and PE), certain consistencies between both models are evident, yet major differences also exist:

1) Both models are significant at the $99 \%$ level of significance.

2) From the significance of the models, the adjusted R-squared values, and the variables that proved to be 
significant, it is evident that the variables in both models can be used to predict the PBV and PE for the organizations in the cement industry in Saudi Arabia.

3) Both models explain a respectable amount of the variation in the dependent variable, although the PBV model seems to have a much higher explanatory power (higher adjusted R-squared). The model can explain more of the variation in its dependent variable: PBV.

4) In both final models, F-Score and LOG_IT proved to be significant in determining the dependent variables.

5) A larger number of variables are predictive of PBV, and they do explain the variation in it to a much higher percentage than they do in the case of PE. Thus, PBV appears to be a more promising variable in studying the stock market in emerging markets. This supports the finding of the studies arguing the superiority of PBV.

\section{Importance of the Study, Limitations, and Future Research}

This study is very focused in nature. It focuses on one industry in the Saudi Arabia stock exchange: the cement industry. While the study considered all fourteen companies in the sector, only nine companies were further studied due to the unavailability of data for the other five companies. While this makes the sample size slightly small, the results of the study are still very valuable for the following reasons:

First, the study, to the best of our knowledge, is among the first studies to focus on emerging markets. It sheds the light on the value relevance of accounting information in emerging markets, a major market that has been greatly overlooked in the literature.

Second, the study covers the period from 2008-2015, which is the entire period for which the data about the companies are available. Thus, the study is comprehensive in nature. Moreover, the study is also comprehensive in terms of the variables it included. The study included variables that represented the most acceptable and agreed upon financial ratios: asset management ratios, liquidity ratios, profitability ratios, solvency ratios, and market analysis ratios. The study also includes the relatively more-recently developed measures M-Score and F-Score, due to their increasing importance in the accounting literature. Thus, the study provides valuable, and relatively comprehensive, information about emerging markets and the value relevance of accounting information in those markets.

This study could lead to many useful research ideas:

- Because the study focuses on one industry in one emerging market, possible extensions of this paper could be accomplished by studying other markets in the same country and in other emerging markets in the region to confirm the findings of this paper. Other research could focus on emerging markets in other parts of the world and compare results with our study. The comparison would be useful in confirming the relevance of accounting information in emerging markets and expanding the list of variables that significantly determine PBV and PE.

- The study provides a comparative analysis of the predictability of PBV and PE in emerging markets, which are used as a proxy for stock price and value of the organization. The study provides clear evidence supporting the superiority of forecasting PBV over PE. While the study did not investigate the relationship between PBV or PE and stock prices or stock performance in emerging markets, the research clearly indicates that PBV is a measure that can be easily studied and predicted. Unlike PE, many financial ratios that organizations normally calculate can be used to predict PBV and, as an extension, stock market performance in the future.

- Other studies can focus on studying other performance measures (other than PBV and PE) and determine their usefulness in studying emerging financial markets.

A comparative study that investigates the determinants of PBV, or the usefulness of accounting information, in developed markets, combined with that of an emerging market (or markets), would be very valuable as well.

\section{Conclusion}

This study examined the cement industry accounting system in Saudi Arabia to assess whether the accounting information provided by the Saudi Arabia stock exchange market has value relevance for stock prices (using PBV and PE ratio as a proxy) and thus can be used to guide investment decisions. The paper examined the effects of six financial ratios and one market-related ratio on PBV and PE. As a result, the paper determines six variables to be significant determinants of PBV: F-Score, inventory turnover (represented in our model by its log values), current ratio, debt-to-equity ratio (also represented in the model by its log values), return on assets, and the number of average daily trading (represented by its log values). All six of these ratios significantly influence 
the Price to Book value and can thus be used to predict the latter. The three variables explain $75.1 \%$ of the variation in PBV, which is considerable. The study also concludes that F-Score and inventory turnover are significant variables in determining the value of PE. Both variables combined explain $23.1 \%$ of the variation in PE.

In summary, the study establishes the relevance of the accounting information to stock prices in the case of the cement industry in Saudi Arabia. The provided regression models can also be used to predict PBV and PE of the stocks in the cement industry in Saudi Arabia. Hence, these models can provide information that helps in making investment decisions in this industry.

To conclude, it is worth mentioning that studying emerging markets is not without its challenges. The data collected from emerging markets are incomplete or unavailable altogether in many cases. Emerging markets are influenced by many factors other than those related to the financial market itself (such as political factors or the governance system of the country in which the financial market operates). Thus, data collected from these markets requires special attention before it is prepared and ready for analysis. Assumptions of normality, and other assumptions specific to the statistical technique used, should be tested meticulously before using the data, due to the previously mentioned reasons. Nevertheless, studying emerging markets adds wealthy information to the current body of knowledge available about accounting relevance and the forecasting of stock prices in developed markets.

\section{References}

Abuzayed, B., Molyneux, P., \& Al-Fayoumi, N. (2009). Market value, book value and earnings: Is bank efficiency a missing link? Managerial Finance, 35(2), 156-179. https://doi.org/10.1108/03074350910923491

Akdeniz, L. A.-S., \& Aslihan Aydogan, K. (2000). A Cross-Section of Expected Stock Returns on the Istanbul Stock Exchange. Russian and East European Finance and Trade, 36(5), 6-26.

Al-Mwalla, M., Al-Omari, A. M., \& Ayad, F. (2010). The relationship between P/E ratio, dividend yield ratio size and stock returns in Jordanian companies: A co-integration approach. International Research Journal of Finance and Economics, 49(49), 91-108.

Alcock, J., \& Gray, P. (2005). Forecasting stock returns using model-selection criteria. Economic Record, 81(253), 135-151. https://doi.org/10.1111/j.1475-4932.2005.00239.x

Alfaraih, M., \& Alanezi, F. (2011). The Usefulness Of Earnings And Book Value For Equity Valuation To Kuwait Stock Exchange Participants. International Business \& Economics Research Journal, 10(1), 73-90. https://doi.org/ 10.19030/iber.v10i1.929

Alshogeathri, M. A. M. (2011). Macroeconomic Determinants of The Stock Market Movements: Empirical Evidence From The Saudi Stock Market. Dissertation, Doctor of Philosophy, Departement of Economics Collage of Art and Sciences, 1-127.

Arab Monetary Fund. (2017). Arab Financial Markets Performance. Retrieved from https://www.amf.org.ae

Aras, G., \& Yilmaz, M. K. (2008). Price-Earnings Ratio, Dividend Yield, and Market-To-Book Ratio To Predict Return on Stock Market: Evidence From the Emerging Markets. Journal of Global Business \& Technology, 4(1), 18-30. https://doi.org/ 10.19030/iber.v10i1.929

Asebedo, G., \& Grable, J. (2004). Predicting mutual fund over-performance over a nine-year period. Journal of Financial Counseling and Planning, 15(1), 1-11. Retrieved from http://www.scopus.com/inward/record.url? eid=2-s2.0-84865854980\&partnerID=40\&md5=22cdc5429e0237ce20c36de22d2bfe59\%5Cnhttp://afcpe.or g/assets/pdf/vol1511.pdf

Asiri, B. K. (2015). How Investors Perceive Financial Ratios at Different Growth Opportunities and Financial Leverages. Journal of Business Studies Quanterly, 6(3), 1-12.

Asiri, B. K., \& Hameed, S. A. (2014). Financial Ratios and Firm's Value in the Bahrain Bourse. Research Journal of Finance and Accounting, 5(7), 1-10.

Bajkowski, J. (2001). Finding the winners among low price-to-book-value stocks. AAII Journal, 13-16.

Bali, T. G., Cakici, N., \& Fabozzi, F. J. (2013). Book-to-Market and the Cross-Section of Expected Returns in International Stock Markets. The Journal of Portfolio Management, 39(2), 101-115. https://doi.org/10.3905/jpm.2013.39.2.101

Bekaert, Geert; Havey, C. R. (1997). Emerging equity market volatility. Journal of Financial Economics, 43(1), 


\section{9-77. https://doi.org/ 10.1016/S0304-405X(96)00889-6}

Beneish, M. D. (1999). The detection of earnings manipulation. Financial Analysts Journal, 55(5), 24-36. https://doi.org/ 10.2469/faj.v55.n5.2296

Bodhanwala, R. J. (2014). Testing the Efficiency of Price-Earnings Ratio in Constructing Portfolio. IUP Journal of Applied Finance, 20(3), 111-118.

Briginshaw, J. A. J. (2003). Essays on fundamental analysis (Unpuplisehd doctoral dissertation). University of California Berkeley.

Chan, L. K. C., Hamao, Y., \& Lakonishok, J. (1991). Fundamentals and Stock Returns in. The Journal of Finance, 46(5), 1739-1764. https://doi.org/10.2307/2328571

Chung, C. Y., Liu, C., Wang, K., \& Zykaj, B. B. (2015). Institutional Monitoring: Evidence from the F-Score. Journal of Business Finance and Accounting, 42(7-8), 885-914. https://doi.org/10.1111/jbfa.12123

Dhatt, M., Kim, Y., \& Mukherji, S. (1999). Relations between stock returns and fundamental variables: Evidence from a segmented market. Asia-Pacific Financial Markets, 6(1996), 221-233. Retrieved from http://link.springer.com/article/10.1023/A:1010071921399

Dreman, D. (1996). Ben Graham was right — again. Forbes, (May, 6), 145.

Dunis, C., \& Reilly, D. (2004). Alternative valuation techniques for predicting UK stock returns. Journal of Asset Management, 5, 230-250. https://doi.org/10.1057/palgrave.jam.2240142

Ganos, T. (2000). Book Value Versus Market Value: An Empirical Examination (Golden Gate University). https://doi.org/10.16953/deusbed.74839

Hall, A. (2015). High F-Score value shares. Investors Chronicle, (Aug. 26), 1-6.

Hyde, C. E. (2014). An Emerging Market Analsyis of the Piotroski F-Score. JASSA, (2), 25-30. Retrieved from http://search.proquest.com/docview/1664811970?accountid=12212

Jensen, G. R., Johnson, R. R., \& Mercer, J. M. (1997). New Evidence on in Size Stock and Price-to-Book Returns Effects in Stock Returns. Financial Analysts Journal, 53(6), 34-42.

Kamo, T. (2011). Integrated computational intelligence and Japanese candlestick method for short-term financial forecasting (unpublished doctoral dissertation).Missouri University of Science and Tehcnology. Missouri.

Kyriazis, D., \& Christou, C. (2013). A Re-examination of the Performance of Value Strategies in the Athens Stock Exchange. International Advances in Economic Research, 19(2), 131-151. https://doi.org/10.1007/s11294-013-9402-7

Le, H. T. T., Tran, V. T., Nguyen, N. T. P., Ngo, N. S., \& Huynh, T. L. D. (2018). The Influence of Peg and F_Score on Stock Return by Valued Investment Portfolios: Empirical Evidence from Vietnam. Asian Economic and Financial Review, 8(3), 366-377. https://doi.org/10.18488/journal.aefr.2018.83.366.377

Lopes, A. B. (2002). The Value Relevance of Brazilian Accounting Numbers: An Empirical Investigation Alexsandro. In University of Sao Paulo, Department of Accounting.

Moridipour, H., \& Farrahipour, Z. (2013). The Evaluation Of The Relationship Between Price ToBook Ratio And Accounting Variables. International Research Journal of Applied and Basic Sciences, 6(10), 1485-1488.

Nettayanun, S. (2017). Value Investing: Circle of Competence in the Thai Insurance Industry. Asia-Pacific Journal of Risk and Insurance, 11(1), 1-33. https://doi.org/10.1515/apjri-2016-0019

Nezlobin, A., Rajan, M. V., \& Reichelstein, S. (2016). Structural properties of the price-to-earnings and price-to-book ratios. In Review of Accounting Studies (Vol. 21). https://doi.org/10.1007/s11142-016-9356-0

Pandey, A., \& Sehgal, S. (2010). Equity Valuation Using Price Multiples: Evidence from India. Asian Academy of Management Journal of Accounting and Finance, 6(1), 89-108.

Penkar, S., \& Deo, P. (2010). A Study on the Financial Characteristics of Nonprofit Corporations. Journal of International Business Research, 9(2), 103-124.

Pervan, I., \& Bartulović, M. (2014). Value relevance of accounting information: Evidence from South Eastern European countries. Economic Research-Ekonomska Istraživanja, 27(1), 181-190. https://doi.org/10.1080/1331677X.2014.947132 
Piotroski, Joseph D. (2000). Value Investing: The Use of Historical Financial Statement Information to Separate Winners from Losers. Journal of Accounting Research, 38(3), 1-41. https://doi.org/10.2307/2672906

Purwanto, P., \& Agustin, J. (2017). Financial Performance towards Value of Firms in Basic and Chemicals Industry. In European Research Studies Journal (Vol. 1). https://doi.org/10.35808/ersj/652

Reza, G., \& Leila, T. (2013). Predictability of stock returns using financial ratios in the companies listed in Tehran Stock Exchange. International Research Journal of Applied and Basic Sciences, 4(12), 4261-4273.

Şamİloğlu, F., Öztop, A. O., \& Kahraman, Y. E. (2017). The Determinants of Firm Financial Performance : Evidence From Istanbul Stock Exchange ( BIST ). IOSR Journal of Economics and Finance, 8(6), 62-67. https://doi.org/10.9790/5933-0806016267

Shamsudin, N., Mahmood, W. M. W., \& Ismail, F. (2013). The Performance of Stock and the Indicators. International Journal of Trade, Economics and Finance, 4(6), 409-413. https://doi.org/10.7763/IJTEF.2013.V4.327

Shen, P. (2000). The P/E Ratio and Stock Market Performance. Economic Review, 85, 23. Retrieved from http://proxy1.ncu.edu/login?url=http://search.ebscohost.com/login.aspx?direct=true \&db=bth\&AN=4258581 $\&$ site $=$ ehost-live

Taani, K., \& Banykhaled, M. (2011). The Effect of Financial Ratios, Firm Size and Cash Flows From Operating Activities on Earnings Per Share: (An Applied Study: On Jordanian Industrial Sector). International Journal of Social Sciences and Humanity Studies, 3(1), 197-205.

Upadhyay, A., \& Bandyopadhyay, G. (2012). Forecasting Stock Performance in Indian Market using Multinomial Logistic Regression. Journal of Business Studies Quarterly, 3(3), 16-39.

Warshavsky, M. (2012). Earnings Quality. Financial Valuation and Litigation Expert, (39), 16-20.

Wu, W. A., \& Boston, M. (2014). The P/E Ratio And Profitability. Journal of Business \& Economics Research, 12(1), 67-76.

\section{Copyrights}

Copyright for this article is retained by the author(s), with first publication rights granted to the journal.

This is an open-access article distributed under the terms and conditions of the Creative Commons Attribution license (http://creativecommons.org/licenses/by/4.0/). 